\title{
THE TIN CONTENT OF THE BLUE-GLAZED HUTTERITE AND HABAN CERAMICS - IMPLICATIONS FOR THE PRODUCTION TECHNOLOGY BASED ON RESULTS OF THE HANDHELD XRF AND ELECTRON MICROPROBE ANALYSES
}

\author{
Bernadett BAJNóczi ${ }^{1}$ - Zoltán MAY ${ }^{2}$ - Anna RidovicS ${ }^{3}$ - Máté SzABÓ ${ }^{1}$ - \\ Géza NAGY ${ }^{1}$ - Mária TóTH ${ }^{1}$ \\ ${ }^{1}$ Institute for Geological and Geochemical Research, Research Centre for Astronomy and Earth Sciences, \\ Hungarian Academy of Sciences, Budaörsi út 45, H-1112 Budapest, Hungary \\ bajnoczi.bernadett@csfk.mta.hu \\ szabo.mate@csfk.mta.hu \\ gnagy@sparc.core.hu \\ toth.maria@csfk.mta.hu \\ ${ }^{2}$ Institute of Materials and Environmental Chemistry, Research Centre for Natural Sciences, Hungarian \\ Academy of Sciences, Magyar tudósok körútja 2, H-1117 Budapest, Hungary \\ may.zoltan@ttk.mta.hu \\ ${ }^{3}$ Hungarian National Museum, Múzeum krt. 14-16, H-1088 Budapest, Hungary \\ anna.ridovics@gmail.com
}

\begin{abstract}
The Hutterites and Habans produced coloured-glazed, mostly blue- and yellow-coloured vessels alongside their white-glazed faience ware. However, the production technology of the coloured-glazed vessels, specifically the nature of the glaze, is a matter of debate among scholars. Both coloured tin glaze and coloured engobe covered with a transparent lead glaze were thought to have been applied on the ceramics.

Around 140 objects of blue-glazed Hutterite and Haban museum objects and archaeological artefacts were analysed using a handheld XRF spectrometer. In addition, small fragments of selected ceramics were studied by electron microprobe analysis (EMPA).

According to the XRF measurements the blue glaze of all except one of the studied Hutterite and Haban ceramics contains tin in variable amounts (from about $0.015 \mathrm{wt} \%$ up to $13 \mathrm{wt} \%$ ). The EMPA technique showed that tin in the form of tin oxide opacifier was deliberately added to the single-layered alkali-lead or lead-alkali glaze. These data confirm that the tin glaze technique was used during production of blue-glazed ceramics, and in this respect they can be regarded as faience. The blue glaze of the Haban vessels produced by a "mining town" workshop contains tin in very low concentrations ( $\mathrm{Sn}<0.2 \mathrm{wt} \%$ by $\mathrm{XRF}$ ), therefore the opacity of the glaze is mainly caused by the abundant silica and arsenate particles. Keywords: ceramic, faience, blue glaze, tin glaze, engobe, Hutterite, Haban, "mining town" workshop.
\end{abstract}

\section{INTRODUCTION}

Beside the dominant white-coloured faience (tin-glazed earthenware) AnabaptistsHutterites and Habans produced coloured-glazed, mainly blue- and yellow-, rarely purple-glazed vessels. However, compared to the white-glazed faience the production technology of the coloured-glazed ware is more disputed among scholars. In the earlier literature different opinions were formed about the production technology, specifically about the nature of the coloured glaze. In contrast to the Czech and Slovakian researchers 
(Landsfeld ${ }^{1}$ ), according to Imre Katona and after him Magda Bunta and Mária Krisztinkovich most of the blue- and yellow-glazed vessels represent a transition between faience and pottery (Bunta 1973: 38-43; Katona 1976: 24-25, 2001: 94-95; HoRváth KRISZTINKOVICH, 2005: 201-205, 291-292). In their opinion the leather-hard vessels were covered with cobalt- or antimony-coloured engobe, i.e. clay slip coating, and fired after drying. Then white, or rarely yellow and green tin-bearing decorations were applied on the vessels, which were finally covered with a transparent lead glaze to produce a bright surface and fired at $880-900^{\circ} \mathrm{C}$. According to Imre Katona the colour intensity and tone of the blue ceramics depends on the amount of cobalt and the colour of the clay used for the engobe: vessels covered with engobe made of clay fired to white have a lavender colour, whereas vessels covered with engobe made of clay fired to red have a violet colour (KATONA 1976: 24-25, 2001: 94-95). According to the same author this Haban technology of using blue engobe had an effect on the Transylvanian pottery as it is shown by the production technology of the ceramics of Szászkézd (now Saschiz in Romania) (KATONA 1974: 64-65). In addition, Katona mentioned that Habans produced another type of blue ceramics, the so-called non-decorated blue vessels, which were covered with only a bluecoloured transparent lead glaze (KATONA 1976: 24-25, 2001: 94-95). The recent Hungarian literature returns to the opinions of the researchers preceding Imre Katona, among others Vince Wartha (WARTHA 1892: 117), who stated that the coloured-glazed vessels are true faience products whose glaze is not a coloured engobe, but a cobalt- or antimonycoloured tin glaze (BALLA - RADVÁNYi 2007; RADVÁNYi 2011: 26).

A research project initiated in 2010 and sponsored by the Hungarian Scientific Research Fund was aimed at preparing the catalogue and computer database of the Anabaptist-Hutterite and Haban ceramics from museum and private collections in Hungary. One of the main objectives of the research is to determine the production technology and provenance of the blue-glazed Anabaptist-Hutterite and Haban ceramics, for which stylistic considerations together with archaeometric analyses are applied.

Non-destructive measurements were performed using a handheld X-ray fluorescence (XRF) analyser to determine the (semi-)quantitative chemical composition of the glaze, the decorations of different colours, as well as the ceramic body. Between June 2009 and February 2015 more than five hundred white- and coloured-glazed objects from the Hutterite to the post-Haban period were analysed using the handheld XRF technique. Objects from museum and private collections (vessels, tiles) and artefacts excavated at several archaeological sites ${ }^{2}$, as well as other related objects, e.g. cobalt-blue ceramics from Szászkézd (now Saschiz in Romania, BAJNóczi et al., 2011), blue-glazed ceramics with

\footnotetext{
${ }^{1}$ Heřman Landsfeld was one of the prominent defenders of the "everything-is-faience" theory (HoRVÁTH - KriszTinKovich 2005: 202).

${ }^{2}$ Analysed museum objects are from the collections of the Hungarian National Museum, Museum of Applied Arts and Museum of Ethnography (Budapest, Hungary), College of the Reformed Church (Sárospatak, Hungary), Austrian Museum of Folk Life and Folk Art (ÖMV, Wien, Austria), Museum of History and Museum of Ethnography of Transylvania (Cluj-Napoca, Romania), Batthyáneum (Alba Iulia, Romania) and Moravian Museum (Brno, Czech Republic). Analysed archaeological artefacts are from the sites of Sárospatak (Hungary), Alvinc (Vințu de Jos, Romania), Szobotist (Sobotište, Slovakia), Buda Castle (Budapest, Hungary), Tavíkovice and Vacenovice (Czech Republic).
} 
sgraffito decoration from Moravia and modern copies were studied. Among them around 140 pieces were blue-glazed Hutterite, Haban (made after c. 1685) and late Haban (made around/after 1730) objects. Beside the handheld XRF analyses, small glaze(d ceramic) samples detached from museum objects and archaeological artefacts were analysed using an electron microprobe (EMP) or a scanning electron microscope (SEM). This highresolution analysis make it possible to distinguish the different layers of a ceramic (body, engobe, opaque and/or transparent glaze layers) and to perform microstructural (textural) and in situ chemical analysis.

In this study the results of handheld XRF analyses performed on the blue-glazed ceramics are shown specifically regarding the tin content of the glaze, which is relevant for the reconstruction of the production technology. In addition, the microstructure and chemical composition of the blue glaze is presented for some selected museum objects and archaeological artefacts.

\section{METHODS}

The non-destructive chemical analysis of the objects was performed using a handheld X-ray fluorescence spectrometer (XRF), NITON XL3t GOLDD+ developed by Thermo Scientific. The analyser is equipped with a high-performance Peltier-cooled energy dispersive Large Drift Detector (LDD) with resolution of $0.195 \mathrm{keV}$. It has an $\mathrm{X}$-ray tube with $\mathrm{Ag}$ anode and $50 \mathrm{kV}$ accelerating voltage. Measuring spot size is about $0.5 \mathrm{~cm}^{2}$ corresponding to a circle $8 \mathrm{~mm}$ in diameter. Each measurement was performed for 120-130 sec, and the concentration of twenty-six elements from $\mathrm{Mg}$ to $\mathrm{U}(\mathrm{Pb}, \mathrm{Sn}$, $\mathrm{Si}, \mathrm{Ca}, \mathrm{Al}, \mathrm{K}, \mathrm{Mg}, \mathrm{P}, \mathrm{S}, \mathrm{Sb}, \mathrm{Zr}, \mathrm{Zn}, \mathrm{Cu}, \mathrm{Ni}, \mathrm{Co}, \mathrm{Fe}, \mathrm{Rb}, \mathrm{Nb}, \mathrm{Mn}, \mathrm{Cr}, \mathrm{V}$, Ti, Ba, Sr, As, Bi) was measured simultaneously. Portable and rechargeable He-cylinder was attached to the XRF analyser for measuring light elements ( $\mathrm{Mg}, \mathrm{Al}, \mathrm{Si}, \mathrm{Cl}, \mathrm{P}, \mathrm{S})$. The 'Mining' calibration method built in by the manufacturer using the fundamental parameters method with Compton normalization was selected for all measurements. If possible, two, sometimes three parallel XRF measurements were performed on the unglazed ceramic body, glaze and decorations of each object. From the parallel measurements performed on the glaze the better data series, i.e. the series with smaller amount of non-measurable part (balance), was chosen for evalution. The detection limit of $\mathrm{Sn}$ in this matrix $(\mathrm{Pb}-\mathrm{Sn}$ bearing glaze $)$ is about the $150 \mathrm{ppm}(0.015 \mathrm{wt} \%)$. Quantitative measurement of $\mathrm{Sn}$ in the $150-450 \mathrm{ppm}$ concentration range is very difficult due to strong overlapping between $\mathrm{K} \alpha 1$ and $\mathrm{K} \alpha 2$ lines of $\mathrm{Sn}$ and $\mathrm{K} \alpha 1$ line of $\mathrm{Ag}$ (the latter belongs to the silver anode target of X-ray tube in the XRF). In the case of a higher concentration of Sn reliable determination (quantification) can be done with the help of other $\mathrm{Sn}$ lines $(\mathrm{K} \beta 1, \mathrm{~K} \beta 2)$ which are free of spectral overlappings (interferences) and are intense enough to obtain proper signal/noise ratio.

From the glaze(d ceramic) samples detached from museum objects and cut from archaeological artefacts cross-sections perpendicular to the glaze-ceramic body interface were prepared by embedding in epoxy resin and polishing. The microstructural and chemical analyses of the cross-sections coated with carbon were performed using a JEOL Superprobe-733 electron microprobe (EMP) equipped with an Oxford Instru- 
ments Inca Energy 200 energy dispersive X-ray spectrometer (EDS). The glazes studied are usually composed of different types of inclusions embedded in a vitreous matrix and contain rounded pores after bubbles. The microstructure of the glaze is visible on the back-scattered electron (BSE) images, where the different types of inclusions are distinguishable from the vitreous matrix and from each other based on the different contrast depending on the average atomic number (e.g. the $\mathrm{SiO}_{2}$ and feldspar particles are darker, whereas the inclusions containing arsenic or tin are brighter than the matrix). The inclusions were identified by qualitative and partly quantitative (spot) EDS analysis.

The 'bulk' chemical composition of the glaze containing the typical inclusions was analysed by area EDS measurements. The analysed areas of the glaze were set as large as possible depending on glaze thickness, but avoiding the glaze-body interface and the outermost part of the glaze ${ }^{3}$. At least three area measurements were performed on each glaze, the analytical totals varied in the range of 90 to $101 \mathrm{wt} \%$. The results were normalised to $100 \%$ and averaged. Several spot analyses were done for the determination of the vitreous matrix composition mostly by using an electron beam of $10 \mu \mathrm{m}$ in diameter to avoid escape of alkali. Spot analyses were performed in transect from the glaze-ceramic body interface to the outer rim of the glaze, the results were normalised to $100 \%$ and averaged. Analytical conditions were at $20 \mathrm{keV}$ and $6 \mathrm{nA}$, count time was $100 \mathrm{sec}$ for the area measurements, and $40 \mathrm{sec}$ for spot measurements. The typical components of the blue glaze were measured, such as $\mathrm{Si}, \mathrm{Pb}, \mathrm{Sn}, \mathrm{Na}, \mathrm{K}, \mathrm{Ca}, \mathrm{Mg}, \mathrm{Al}, \mathrm{Fe}$ and $\mathrm{Cl}$, as well as $\mathrm{Co}, \mathrm{Ni}$, $\mathrm{As}, \mathrm{Cu}$ and $\mathrm{Zn}$ originating from the blue pigment (see Ridovics et al. 2015). Presence of Sn was intentionally confirmed in the energy dispersive spectra even if the Oxford Instruments INCA software did not identify its lines. Concentrations of elements are reported in oxide form (except $\mathrm{Cl}$ ). Quantitative concentration data were calculated based on the intensity of the characteristic X-ray lines emitted by the elements of the samples excited by electrons after substitution of the background and comparison with standards. Natural and artificial materials of the Taylor Co. (USA) and artificial glasses of the Smithsonian Institution (USA) were used as standards. PAP correction - due to the matrix effects originating from the compositional differences between the studied samples and the standards - was automatically made by the INCA software. The detection limit of the spot (matrix) analyses is about $0.6 \mathrm{wt} \%$ for $\mathrm{SnO}_{2}$, the limit of the areal analyses is lower by a factor of 0.63 (BAJNóCZI et al. 2014).

Detection of low levels of tin (few tin oxide particles) in the cross-sections of glaze during the area analyses made by the energy dispersive X-ray spectrometer attached to an EMP or a SEM (in the analytical conditions discussed above) is difficult. Firstly, tiny tin oxide particles are distributed heterogeneously in the glaze, therefore it is not certain that they fall in the area analysed by EDS. Secondly, the L lines of tin overlap with the K lines of potassium in the X-ray spectrum at $3.3-3.6 \mathrm{KeV}$, which is especially problematic if the glaze is rich in potassium.

\footnotetext{
${ }^{3}$ Analysed areas were the following: bowl (inv. no. MNM 1954.395) - from $104 \times 84 \mu \mathrm{m}$ to $208 \times 170 \mu \mathrm{m}$; jug (inv. no. IMM 2900) $-125 \times 101 \mu \mathrm{m}$ to $146 \times 118 \mu \mathrm{m}$; tazza (inv. no. 2010.06 .23 .1 ) - from $140 \times 140 \mu \mathrm{m}$ to $175 \times 175 \mu \mathrm{m}$; fragment of a jug (inv. no. BTM TA15) - from $110 \times 100 \mu \mathrm{m}$ to $400 \times 180 \mu \mathrm{m}$.
} 


\section{RESULTS}

\section{HANDHELD XRF ANALYSES}

In this study only the Sn concentration data of the handheld XRF measurements performed on the blue glaze are discussed in detail.

The Sn concentration measured in the blue glaze of the objects varies in a wide range from $0.015 \mathrm{wt} \%$ to $13.3 \mathrm{wt} \%$ (Fig. 1). Sn was detected in all but one of the studied blue glazes, the lead glaze without any tin covers a tile made in Moravia. Less than $1 \mathrm{wt} \%$ concentration of Sn was measured in the blue glaze of almost half of the analysed objects. Among them thirty-two pieces belonging to one specific workshop, the so-called "mining town" workshop (see Ridovics et al. 2015) contain $<0.2 \mathrm{wt} \% \mathrm{Sn}$. The rest of the objects show a wider Sn concentration range from 1 up to $6.7 \mathrm{wt} \%$ (Fig. 1). The blue glaze of one museum object (Inv. n. ZMM 20.469, a bowl from the Moravian Museum, Brno, Czech Republic) and three archaeological artefacts - namely, one from the Buda Castle (Inv. n. BTM TA15), second one from the Haban settlement at Sárospatak (Inv. n. Sp. 141), Hungary, and the third one from Szobotist (Inv. n. NM 2013.54.24) - exhibit the highest Sn concentrations $(8.0 \mathrm{wt} \%, 8.4 \mathrm{wt} \%, 9.1 \mathrm{wt} \%$ and $13.3 \mathrm{wt} \% \mathrm{Sn}$, respectively) (Fig. 1).

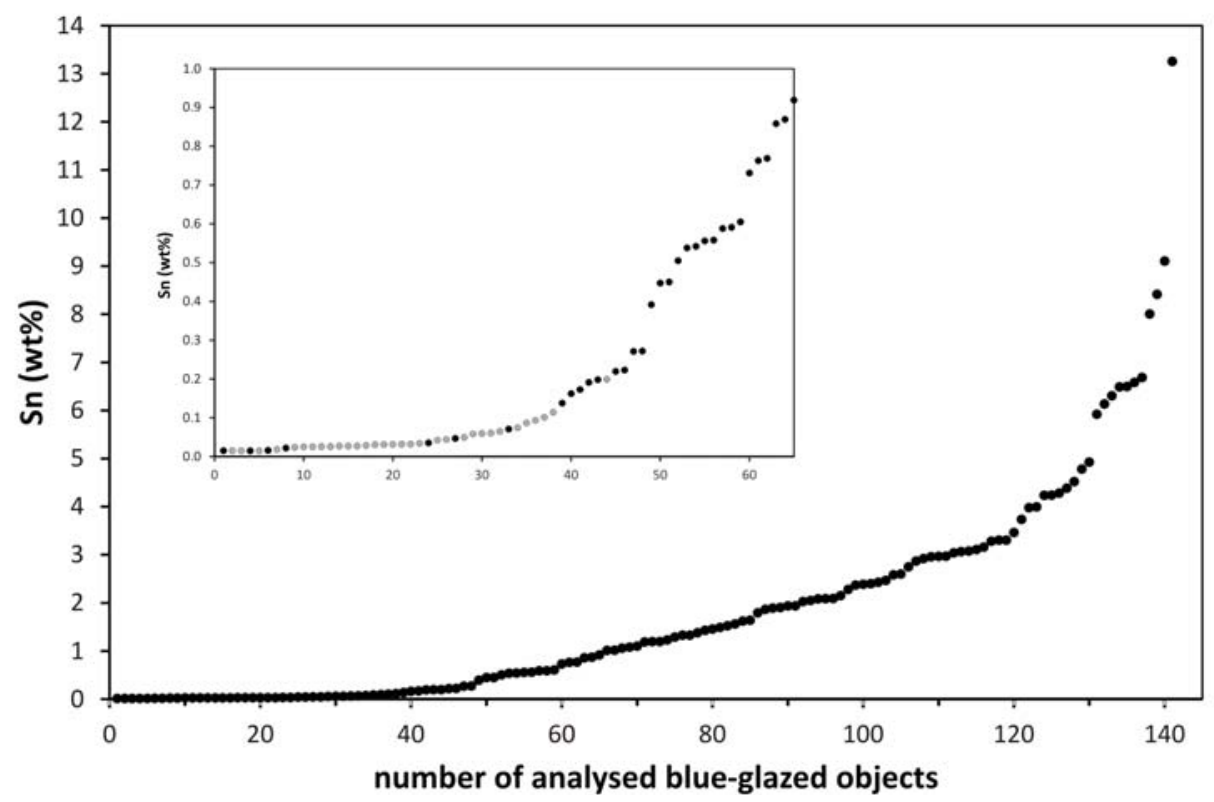

Fig. 1. Sn content (in element wt $\%$ ) of the blue glazes analysed by handheld XRF.

Notes: data are organized according to the increasing Sn concentration of the objects. The low tin concentration region $(\mathrm{Sn}<1 \mathrm{wt} \%$ ) of the diagram is enlarged on the inserted figure.

Objects produced by the "mining town" workshop are shown with grey dots.

The blue lead glaze without tin covering a Moravian tile is not indicated on the diagram. 


\section{ELECTRON MICROPROBE ANALYSES}

Microstructure and chemistry of the blue glaze were studied in the case of some selected ceramics. One of the reasons for the selection was to verify the validity of the very small (hundreds of ppm) Sn concentration detected in the blue glaze of several objects by the handheld XRF technique, i.e. whether actual presence of intentionally added tin (tin oxide particles) can be detected. Selected samples include small blue glaze fragments of a bowl and a jug showing low Sn concentrations ( 0.015 and $0.065 \mathrm{wt} \% \mathrm{Sn}$, respectively) by handheld XRF, both vessels are products of the "mining town" workshop. To illustrate the microstructure of a glaze relatively rich in tin, a fragment of a tazza (bowl on stand) excavated at the remnants of a 17th-century gun-foundry in the outer castle of Sárospatak was chosen. During the archaeological excavations of the Buda Castle (Budapest) numerous fragments of blue-glazed 17th-century Haban vessels were found. One of them is presented here as a representative of ceramics covered with blue glazes with different hue at different sides, the lighter one shows relatively high concentration of tin $(8.4 \mathrm{wt} \% \mathrm{Sn}$ by XRF analysis).

\section{Bowl with monogram F:D: and date 1731 (Inv. n. MNM 1954.395, Hungarian National Museum) (Fig. 2)}

The thrown bowl with a broad rim and deep well with unglazed bottom on the reverse side. Besides the characteristic Haban motifs painted in white and yellow (the date and a monogram placed in a wreath, a painted bunch of flowers in the well of the bowl), the decoration includes roughly drawn, rather crowded plant motifs facing opposite directions around the edge. On the basis of production technology and stylistic consideration, the piece is the product of the "mining town" workshop. $0.015 \mathrm{wt} \%(150 \mathrm{ppm}) \mathrm{Sn}$ was detected in the blue glaze by the handheld XRF analyser (Table 1).

The thickness of the single-layered glaze varies between 90 and $180 \mu \mathrm{m}$. The vitreous matrix is brighter in patches due to locally higher lead content (Fig. 2c). High amounts of inclusions are distributed more or less homogenously in the matrix. Rounded or slightly angular dark quartz and feldspar particles of $20-40 \mu \mathrm{m}$ size and very abundant dark $\mathrm{SiO}_{2}$ inclusions of up to $5 \mu \mathrm{m}$ size are present; the shape of the latter phases is rounded, elongated or tabular sometimes with well-visible crystal faces. Silica inclusions are aggregated into rows or clusters, or overgrown on quartz grains. The bright inclusions are mainly calcium-potassium and calcium-potassium-lead arsenate particles, according to the energy dispersive spectra they contain minor amounts of sodium, chlorine and phosphorous as well. Arsenate inclusions are partly scattered in the glaze as rounded or angular particles of some $\mu \mathrm{m}$ size or their aggregates and partly accumulate at the body-glaze interface in the form of stripes (Fig. 2c,d,f). A rounded nickel arsenide particle with a small amount of copper was also found. Bright tin oxide particles of some $\mu \mathrm{m}$ size occur very rarely in the glaze as individual, rounded or angular inclusions and their aggregates (Fig. 2d,e).

Alkali, namely potassium $\left(\mathrm{K}_{2} \mathrm{O}\right)$ dominates among the fluxes in the 'bulk' chemical composition of the glaze with $\mathrm{K}_{2} \mathrm{O}+\mathrm{Na}_{2} \mathrm{O}$ (total alkali) content of $12.5 \mathrm{wt} \%$ and $\mathrm{K}_{2} \mathrm{O} / \mathrm{Na}_{2} \mathrm{O}$ 

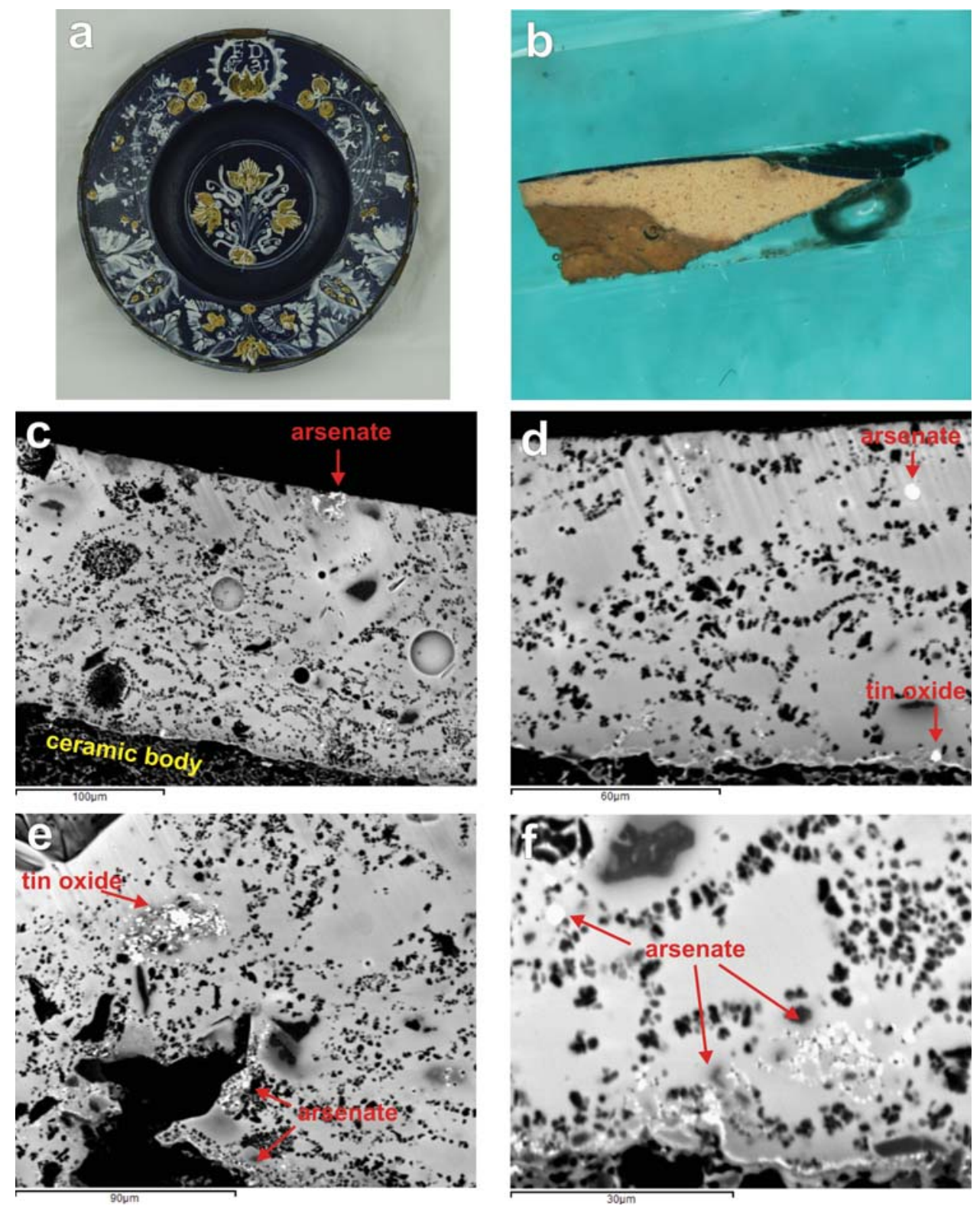

Fig. 2. a) Bowl with monogram F:D: and date 1731 (Inv. n. MNM 1954.395, Hungarian National Museum); b) Cross-section of a small detached sample showing the blue glaze on the ceramic body; c-f) Back-scattered electron images showing the microstructure and inclusions of the blue glaze.

ratio of 8.6 (Table 2). The $\mathrm{PbO}$ content $(6.6 \mathrm{wt} \%)$ is far less than the total alkali content, therefore the glaze is of alkali-lead type. According to the area measurements the $\mathrm{SnO}_{2}$ content is $0.45 \pm 0.13 \mathrm{wt} \%$, which is around the detection limit for tin. Beside cobalt $(0.7$ 
$\mathrm{wt} \% \mathrm{CoO})$, other components originating from the pigment are present such as nickel $(0.7$ $\mathrm{wt} \% \mathrm{NiO})$ and arsenic $\left(4.5 \mathrm{wt} \% \mathrm{As}_{2} \mathrm{O}_{3}\right)$; this glaze contains the highest amount of arsenic among the ceramics studied in detail in this study (Table 2). The presence of $\mathrm{Zn}$ was also detected $(0.6 \mathrm{wt} \% \mathrm{ZnO})$.

\section{Jug with the date 1726 (Inv. n. IMM 2900, Museum of Applied Arts) (Fig. 3)}

The date on this oval, melon-bellied jug with a wide mouth has been placed on either side of the handle. A large bunch of flowers painted in yellow occupies the side opposite the handle between double white stripes starting from the base of the handle. This piece is also a product of the "mining town" workshop.

The handheld XRF analyser detected $0.065 \mathrm{wt} \%(650 \mathrm{ppm}) \mathrm{Sn}$ in the blue glaze (Table 1). The thickness of the single-layered glaze is $120-160 \mu \mathrm{m}$. The glaze shows inhomogeneity, namely its upper 20-30 $\mu \mathrm{m}$ thick part is brighter due to the higher lead content (Fig. $3 c, e)$. However, this phenomenon does not indicate a second glaze layer, rather it can be the result of element diffusion causing apparent enrichment of lead at the outer side of the glaze. Similarly to the above bowl, high amounts of dark inclusions are scattered homogenously throughout the blue glaze; the inclusions are rounded or slightly angular quartz and K-feldspar grains of 20-30 $\mu \mathrm{m}$ size and abundant, rounded or tabular $\mathrm{SiO}_{2}$ particles of up to about 5 $\mu \mathrm{m}$ size. Most of the bright inclusions are lead-calcium and calcium-lead arsenates containing some sodium, potassium, chlorine and phosphorous. Arsenate inclusions are rounded or angular particles as well as tabular and needle-like crystals, the latter preferentially occur in pores and at the rim of the pores. Other bright particles are angular tin oxide inclusions (Fig. $3 d$ ), which can hardly be differentiated from arsenate, and sometimes occur together with it. In accordance with the higher Sn content detected by the handheld XRF more tin oxide particles of some $\mu \mathrm{m}$ size were observed in the blue glaze compared with the above bowl. A few individual or aggregated lead antimonate inclusions up to $5 \mu \mathrm{m}$ size are also present (Fig. 3f), they also contain additional calcium, iron, arsenic(?) and manganese.

The 'bulk' glaze (including the lead-rich outer part) is of lead-alkali type with 14.4 wt $\% \mathrm{PbO}, 11.2 \mathrm{wt} \% \mathrm{~K}_{2} \mathrm{O}+\mathrm{Na}_{2} \mathrm{O}$ and $\mathrm{K}_{2} \mathrm{O} / \mathrm{Na}_{2} \mathrm{O}$ ratio of 5 (Table 2). The 'bulk' $\mathrm{SnO}_{2}$ content is $0.07 \pm 0.35 \mathrm{wt} \%$ indicating that although tin oxide particles occur in the glaze (and in the areas measured by EDS), the concentration of tin (reported as $\mathrm{SnO}_{2}$ ) is below the detection limit of the EDS. Concentrations of the components originating from the pigment are similar to that of the previous glaze $(0.8 \mathrm{wt} \% \mathrm{CoO}, 0.7 \mathrm{wt} \% \mathrm{NiO}$ and $0.8 \mathrm{wt} \%$ $\mathrm{ZnO})$, except arsenic, whose concentration is nearly half of that of the previous glaze (2.6 $\mathrm{wt} \% \mathrm{As}_{2} \mathrm{O}_{3}$ ) (Table 2).

3. Tazza (bowl on a stand) (Fragment for the gun-foundry, Sárospatak, Hungary, 17th century, Inv. n. 2010.06.23.1, earlier published by BAJNÓCZI et al., 2014) (Fig. 4)

Fragment of a tazza with opaque blue glaze on the stand and on the external side of the dish and white glaze with decorations on the internal side of the dish (Fig. 4). The back of the footed bowl is covered with an even blue glaze. The richness of the ornamentation on the white-glazed inner side is apparent despite the fragmented state. The well is 

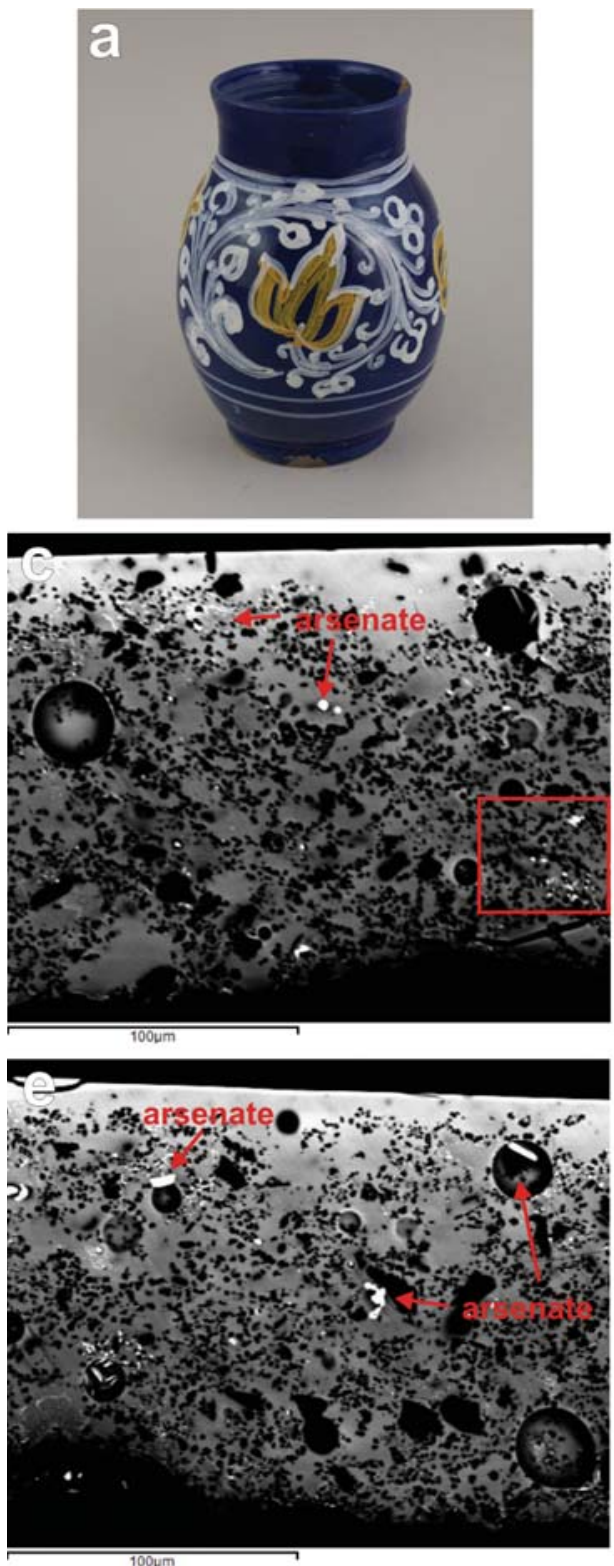

Fig. 3. a) Jug with the date 1726 (Inv. n. IMM 2900, Museum of Applied Arts); b) Cross-section of a small detached sample showing the blue glaze; $\mathrm{c}-\mathrm{f}$ ) Back-scattered electron images showing the microstructure and inclusions of the blue glaze. Part of fig. $\mathrm{c}$ indicated by the rectangle is enlarged in fig. $\mathrm{d}$.

decorated with a colourful floral motif framed with a double blue line, from which a green flower with a yellow centre seen from above has survived. The four petals are emphasised with a brown contour and a tiny circle at their tip. The whole edge of the bowl was prob-
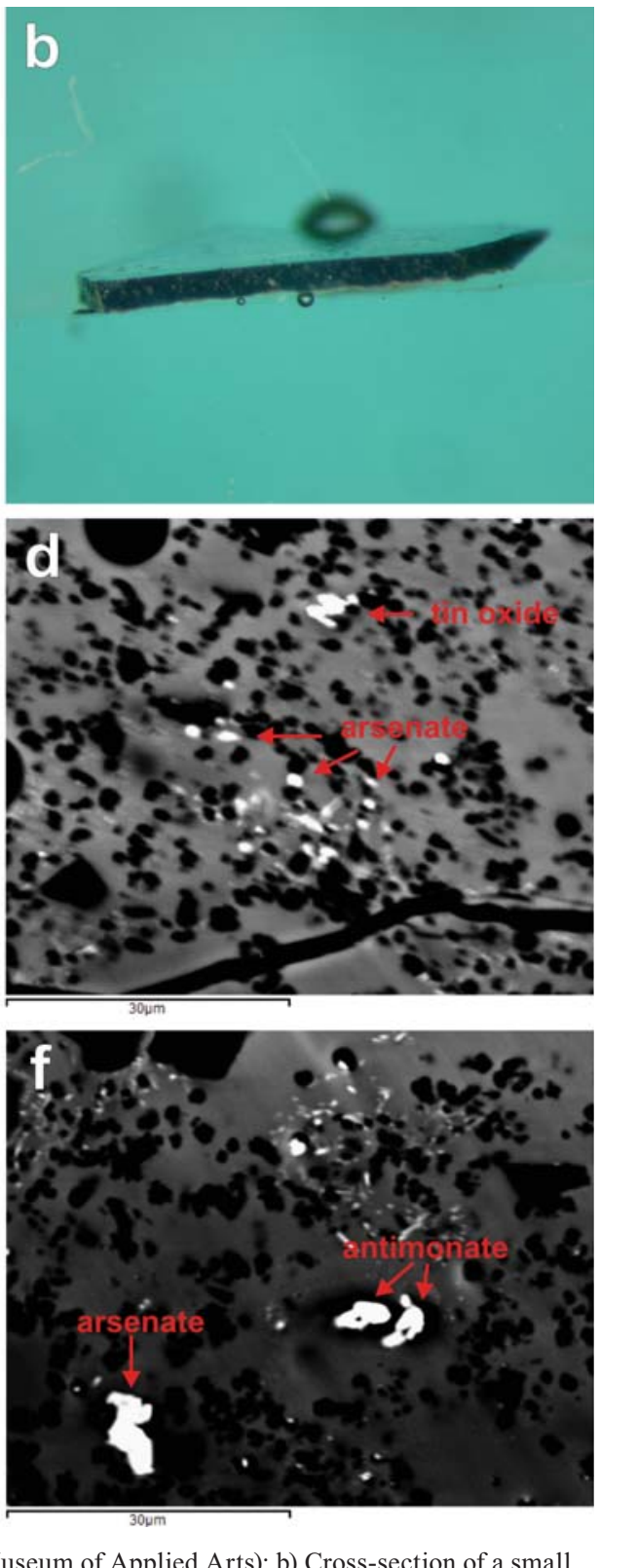

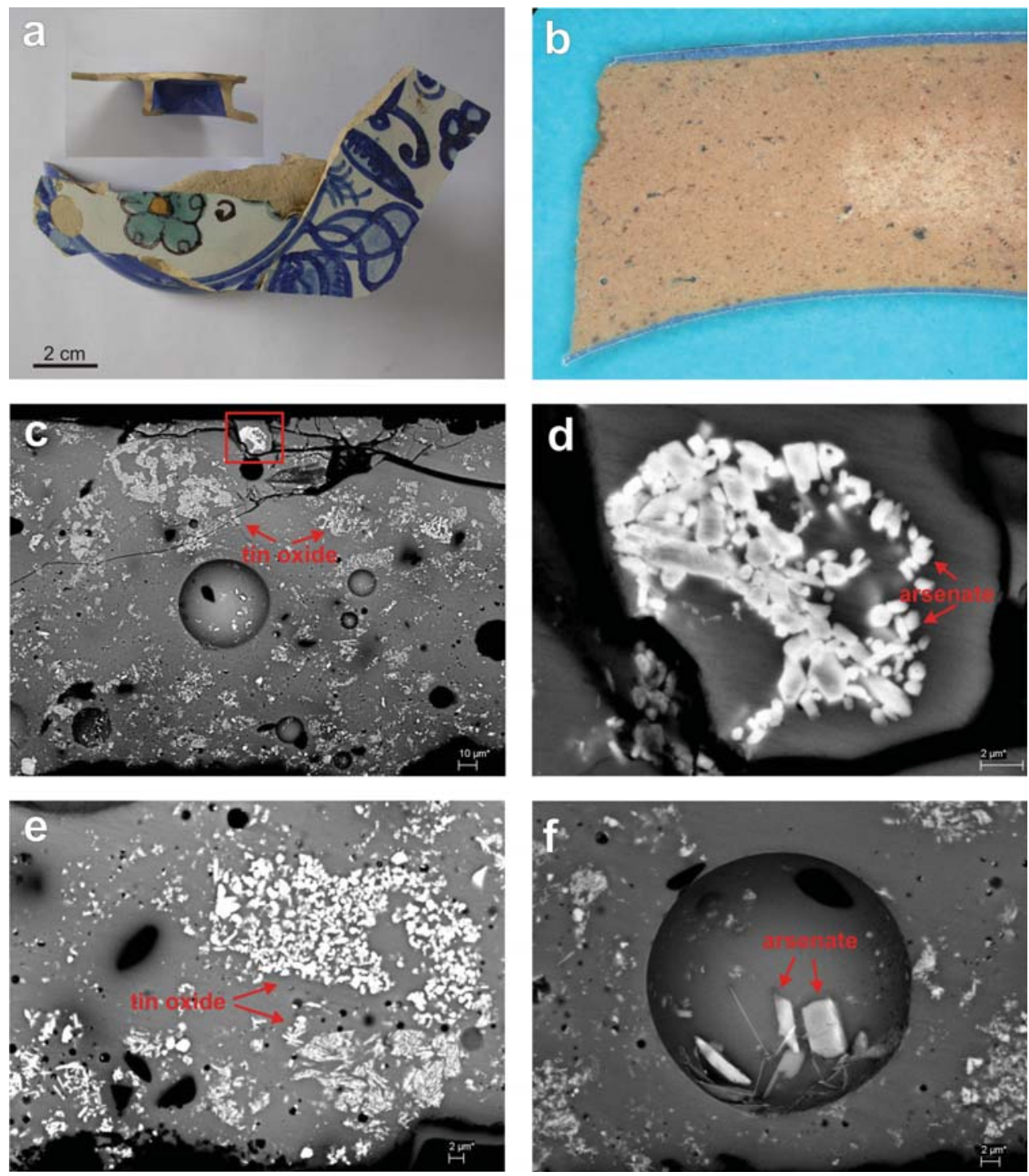

Fig. 4. a) Tazza (bowl on a stand, gun-foundry, outer castle of Sárospatak, 17 ${ }^{\text {th }}$ century, Inv. n. 2010.06.23.1); b) Cross-section of a ceramic slice cut from the stand showing the blue glaze on both sides of the ceramic body; $\mathrm{c}-\mathrm{f}$ ) Back-scattered electron images showing the microstructure and inclusions of the blue glaze. Part of fig. $\mathrm{c}$ indicated by the rectangle is enlarged in fig. $\mathrm{d}$.

ably covered with a floral motif painted in two shades of blue, the so-called camieau blue floral motif, which can be linked to the style popular in the late $17^{\text {th }}$ century, known in the literature as the "Odler" workshop style. 
Table 1. Chemical composition of the blue glaze of some selected objects measured by handheld XRF analyser (expressed in element wt\%).

\begin{tabular}{|c|c|c|c|c|c|c|c|c|c|c|c|c|}
\hline Element $(w t \%)$ & $\mathrm{Si}$ & $\mathrm{Pb}$ & Sn & $\mathrm{Fe}$ & Co & $N i$ & $C u$ & $Z n$ & $S b$ & $B i$ & $M n$ & As \\
\hline \multicolumn{13}{|l|}{ bowl } \\
\hline $\begin{array}{l}\text { inv. n. MNM } 1954.395 \\
\text { jug }\end{array}$ & 29.04 & 3.41 & 0.015 & 0.94 & 0.49 & 0.43 & 0.05 & 0.31 & 0.00 & 0.37 & 0.05 & 6.52 \\
\hline inv. n IMM 2900 & 25.45 & 6.80 & 0.065 & 0.90 & 0.45 & 0.42 & 0.10 & 0.42 & 0.01 & 0.30 & 0.05 & 4.82 \\
\hline \multicolumn{13}{|l|}{ tazza } \\
\hline inv. n. 2010.06.23.1 & 15.02 & 11.14 & 2.97 & 0.31 & 0.29 & 0.08 & 0.00 & 0.00 & 0.00 & 0.05 & 0.00 & 1.00 \\
\hline \multicolumn{13}{|c|}{ fragment of a jug (?), inv. no. BTM TA15 } \\
\hline outer blue glaze ${ }^{1}$ & 23.24 & 20.61 & 2.11 & 0.56 & 0.31 & 0.16 & 0.04 & 0.03 & 1.51 & 0.20 & 0.16 & 1.05 \\
\hline inner light blue glaze & 20.36 & 23.76 & 8.42 & 0.42 & 0,14 & 0.20 & 0.24 & 0.01 & 0.15 & 0.07 & 0.19 & 0.61 \\
\hline
\end{tabular}

${ }^{1}$ outer blue glaze together with yellow decoration was measured

The handheld XRF analyser detected $2.97 \mathrm{wt} \% \mathrm{Sn}$ in the blue glaze (Table 1). The thickness of the single-layered blue glaze varies between 180 and $300 \mu \mathrm{m}$. A few quartz and feldspar particles and lots of tin oxide inclusions are present and distributed heterogeneously in the glaze (Fig. 4c). Two types of cassiterite can be detected: relatively large, up to $10 \mu \mathrm{m}$ size angular particles as well as small needles up to $1-2 \mu \mathrm{m}$ in size, which frequently form aggregates of up to $40 \mu \mathrm{m}$ in size (Fig. 4e). Idiomorphic, tabular and needlelike, chlorine- and phosphorous-bearing lead-calcium arsenate crystals in some $\mu \mathrm{m}$ size are preferentially deposited inside the pores and also dispersed within the vitreous matrix (Fig. 4d,f), however, their amount is smaller than in the above-mentioned two glazes.

The 'bulk' glaze is of lead-alkali type with $28.1 \mathrm{wt} \% \mathrm{PbO}, 8 \mathrm{wt} \% \mathrm{~K}_{2} \mathrm{O}+\mathrm{Na}_{2} \mathrm{O}$ content and $\mathrm{K}_{2} \mathrm{O} / \mathrm{Na}_{2} \mathrm{O}$ ratio of 1.6 (Table 2). The 'bulk' energy dispersive X-ray measurements indicate $11 \mathrm{wt} \% \mathrm{SnO}_{2}$ content in average. Chlorine has a detectable amount of $1 \mathrm{wt} \%$. Concentration of cobalt originating from the pigment is similar to that of the above-mentioned two objects $(0.7 \mathrm{wt} \% \mathrm{CoO})$, whereas the nickel and arsenic contents are lower $(0.2 \mathrm{wt} \%$ $\mathrm{NiO}, 0.9 \mathrm{wt} \% \mathrm{As}_{2} \mathrm{O}_{3}$ ) (Table 2).

\section{Fragment of a jug(?) (Locality: Buda Castle, Budapest, Csónak u. 1-3, $17^{\text {th }}$ century} (before 1685), Inv. n. BTM TA15) (Fig. 5)

The fragment is covered with a blue glaze on the outer/decorated side and a light blue glaze on the inner side. Decorations are a yellow branch with pine needles and a white motif. The handheld XRF analyser detected $2.11 \mathrm{wt} \% \mathrm{Sn}$ in the outer blue glaze together with the yellow decoration and $8.42 \mathrm{wt} \% \mathrm{Sn}$ in the inner light blue glaze (Table 1). The outer blue glaze is $110-170 \mu \mathrm{m}$ thick and the inner light blue glaze is $150-190 \mu \mathrm{m}$ thick, both are single-layered. The glazes contain rounded or slightly angular quartz and feldspar grains in similar quantity; however, they differ in the amount of the bright particles (Fig. 5). The inner light blue glaze contains abundant tin oxide inclusions: both angular particles up to 5 $\mu \mathrm{m}$ in size and aggregates of tiny needles up to $50 \mu \mathrm{m}$ in size are present (Fig. $5 c, d$ ). Compared to the light blue glaze, much fewer tin oxide particles occur in the outer blue glaze (Fig. 5e,f). In both blue glazes chlorine-bearing lead-calcium arsenate particles in several tens of $\mu \mathrm{m}$ size preferentially occur as needles in the rounded pores; higher amounts of 

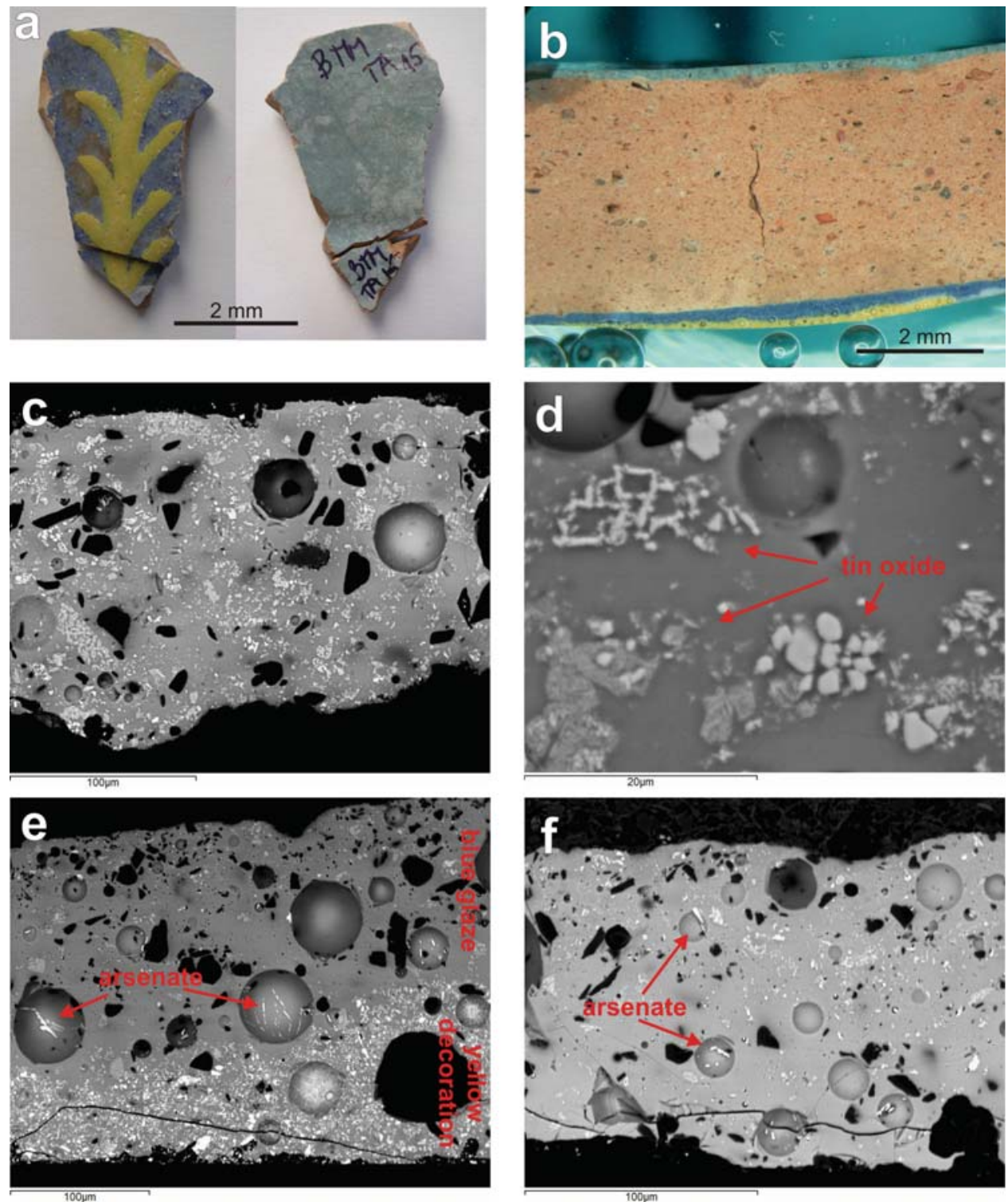

Fig. 5. a) Fragment of a jug(?) (Buda Castle, Budapest, Csónak u. 1-3, 17 th century (before 1685), Inv. n. BTM TA15); b) Cross-section of a ceramic slice cut from the sample showing the blue glaze with yellow and white decorations on the outer side and light blue glaze on the inner side of the ceramic; $\mathrm{c}-\mathrm{d}$ ) Back-scattered electron images showing the microstructure and inclusions of the inner light blue glaze; e-f) Back-scattered electron images showing the microstructure and inclusions of the outer blue glaze.

arsenate particles are present in the outer blue glaze. A few angular, bright lead antimonate particles with some calcium and sodium content were also detected in the light blue glaze. 


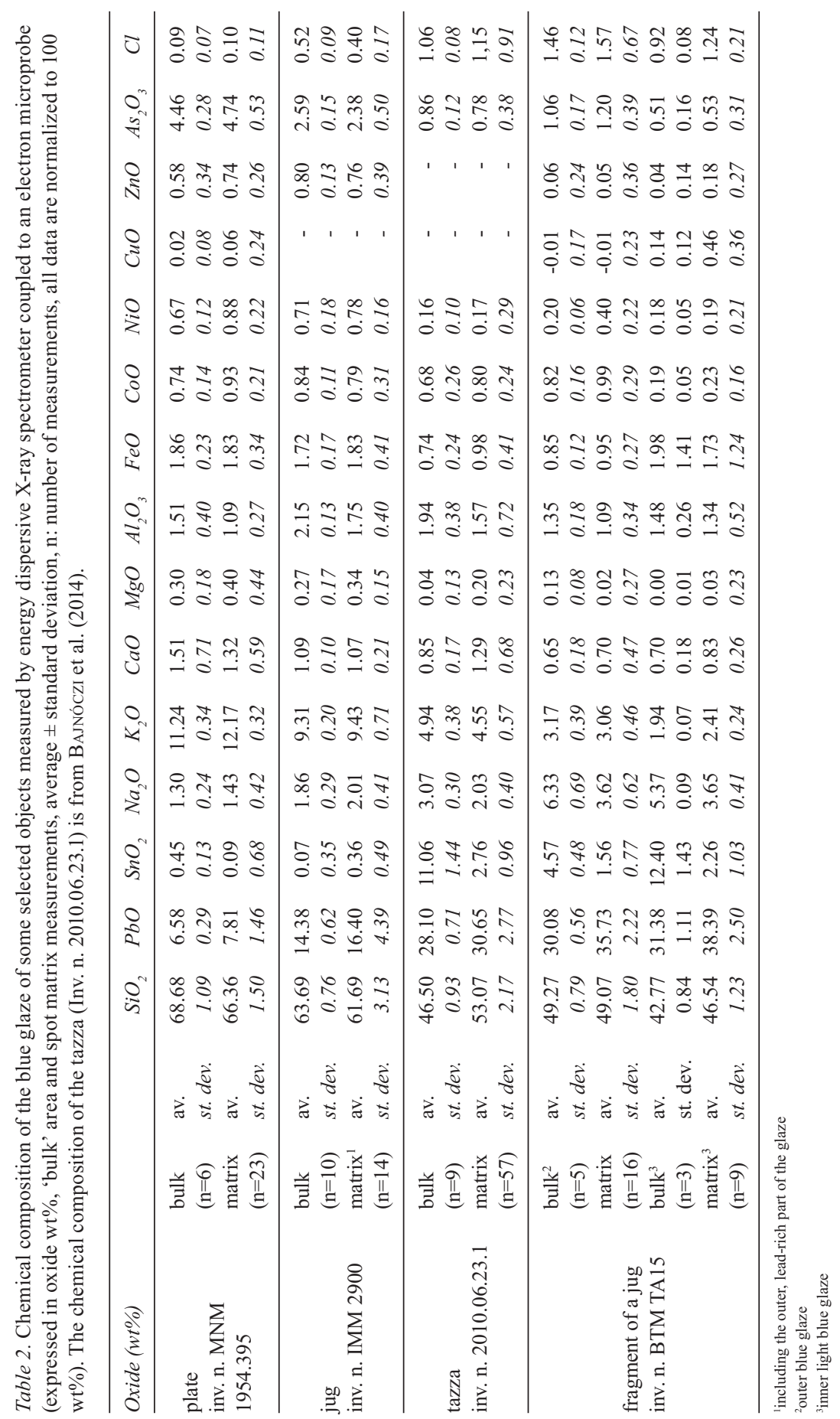


The inner light blue glaze is of lead-alkali type with $31.4 \mathrm{wt} \% \mathrm{PbO}, 7.3 \mathrm{wt} \% \mathrm{~K}_{2} \mathrm{O}+\mathrm{Na}_{2} \mathrm{O}$ and $\mathrm{K}_{2} \mathrm{O} / \mathrm{Na}_{2} \mathrm{O}$ ratio of 0.4 ('bulk' composition, Table 2). The chlorine content is around $1 \mathrm{wt} \%$. The 'bulk' inner blue glaze contains $12.4 \mathrm{wt} \% \mathrm{SnO}_{2}$, whereas in accordance with the fewer tin oxide particles seen on the back-scattered electron images, the outer blue glaze contains only $4.6 \mathrm{wt} \% \mathrm{SnO}_{2}$. The outer blue glaze is also of lead-alkali type with $30.1 \mathrm{wt} \% \mathrm{PbO}, 9.5 \mathrm{wt} \% \mathrm{Na}_{2} \mathrm{O}+\mathrm{K}_{2} \mathrm{O}, \mathrm{K}_{2} \mathrm{O} / \mathrm{Na}_{2} \mathrm{O}$ ratio of 0.5 and $1.5 \mathrm{wt} \%$ chlorine content. In accordance with the darker blue colour of the outer glaze, the concentrations of the components originating from the pigment, mainly cobalt and arsenic are higher than that in the inner glaze $\left(0.8 \mathrm{wt} \% \mathrm{CoO}, 0.2 \mathrm{wt} \% \mathrm{NiO}, 1.1 \mathrm{wt} \% \mathrm{As}_{2} \mathrm{O}_{3}\right.$ vs. $0.2 \mathrm{wt} \% \mathrm{CoO}, 0.2 \mathrm{wt} \%$ $\mathrm{NiO}, 0.5 \mathrm{wt} \% \mathrm{As}_{2} \mathrm{O}_{3}$, Table 2).

\section{DISCUSSION}

According to the handheld XRF measurements the blue glaze of all but one Hutterite and Haban ceramics studied up to now contains tin in variable amounts from about 0.015 wt $\%$ (150 ppm, the detection limit of the XRF) up to more than $10 \mathrm{wt} \% \mathrm{Sn}$. Based on the production technology and stylistic considerations thirty-two vessels form a separate group among the studied Haban pieces. These objects are products of a specific, so-called "mining town" workshop (RIDOvics et al. 2015) and might have been produced in one of the towns situated on the upper reaches of river Hron (Garam in Hungarian) in Slovakia, around/in Zvolen (Zólyom) or Banská Bystrica (Besztercebánya). The workshop operated from the end of the $17^{\text {th }}$ century, its most productive period was in the 1720 s and 1730 s, however, its style survived for decades after that (Ridovics et al. 2015). The characteristic of the blue glaze of the "mining town" vessels is the presence of uranium originating from the cobalt pigment (RIDOvics et al. 2015). The analyses of the present study indicate another characteristic of this specific group, the very low Sn content, i.e. up to $0.2 \mathrm{wt} \%$ by handheld XRF. The presence of tin detected in hundreds of ppm by XRF in the blue glaze of the "mining town" vessels was verified by the microstructural analyses: a few tin oxide particles are present and heterogeneously distributed in the blue glaze of a bowl $(0.015 \mathrm{wt} \% \mathrm{Sn})$ and a jug $(0.065 \mathrm{wt} \% \mathrm{Sn})$. At least a very small amount of tin seems to be systematically present in the blue glaze of the "mining town" vessels, which suggest deliberate use of tin oxide as opacifier rather than accidental impurity.

A single-layer blue glaze with variable amount of tin oxide particles was observed on the ceramics selected for detailed microstructural examination in the present study. Examination of the cross-sections of other glaze fragments, not presented in this paper, has not detected coloured engobe covered with a transparent lead glaze. On the whole both the handheld XRF data and the EMPA results support the application of tin-glaze (faience) technique during production of blue-glazed Hutterite and Haban ceramics.

The chemical composition of the blue glaze of the ceramics studied in detail is not homogeneous. The blue glazes of the bowl and the jug, both containing very small amounts of tin and produce by the "mining town" workshop, are alkali-rich with more than $10 \mathrm{wt} \%$ $\mathrm{K}_{2} \mathrm{O}+\mathrm{Na}_{2} \mathrm{O}$. The dominance of potassium among the alkalis with the very small amount of 
chlorine ( 0.1 and $0.5 \mathrm{wt} \%$, respectively) indicates the dominant use of K-bearing flux (wine lees, tartar) in the blue glaze. Regarding the blue glaze of the tazza from Sárospatak, lead is the dominant flux and potassium is the dominant alkali; however, the presence of sodium with the $1 \mathrm{wt} \%$ chlorine indicates addition of a Na-rich material, most probably common salt as well. In contrast to these objects, both in the inner and the outer lead-rich blue glaze covering the archaeological artefact from the Buda Castle (fragment of a jug) sodium is the dominant alkali, and together with the detectable chlorine (1-1.5 wt\%) indicates that a significant part of the alkali flux was common salt. According to the classification elaborated by Tite et al. (1998) for historic ceramic glazes based on the dominant flux, the studied ceramics are covered with both alkali-lead and lead-alkali glazes.

The presence of alkali, a water-soluble flux in the blue glaze indicates that a vitreous frit made - at least - from alkali and silica (the latter is mainly in the form of sand) was used for preparation of the glaze suspension. Regarding the bowl and the jug a small amount of additional lead-bearing flux, in the form of lead oxide, was added to the glaze suspension, maybe to the alkali and the silica before fritting. Tin was added to the glaze in the form of lead-tin calx or calcine that is a mixture of lead and tin oxides. Heterogeneous distribution of the abundant tin oxide particles in the blue glaze of the studied archaeological artefacts indicates that the frit was mixed with the lead-tin calx. The rounded and angular quartz and feldspar particles occurring in the glaze are incompletely melted relicts originated from the frit or from the further sand added to the glaze mixture. In addition to quartz, many newly-formed $\mathrm{SiO}_{2}$ crystallites were detected in the blue glaze of two studied objects (the bowl and the jug), these crystallites are probably cristobalite and/or tridymite ( $\mathrm{SiO}_{2}$ polymorphs) (MolerA et al. 1999; PrADELL et al. 2010). Cristobalite is usually regarded as a compound indicative of a high firing temperature $\left(>1400^{\circ} \mathrm{C}\right)$, but on the contrary, it can form as early as the melt is produced in a mixture of quartz and alkaline glass (PRADELL et al. 2010). This statement harmonizes well with our observations showing that newly-formed $\mathrm{SiO}_{2}$ crystals are present in the alkali-rich blue glazes of the bowl and the jug in which the concentration of alkali $\left(\mathrm{K}_{2} \mathrm{O}+\mathrm{Na}_{2} \mathrm{O}\right)$ is in the same range or higher than the concentration of lead $(\mathrm{PbO})$. In this respect the blue glaze of these two objects resembles the blue glaze of the cobalt-blue ceramics from Szászkézd (Saschiz, Romania), which also contains many newly-formed silica particles (BAJNóczI et al. 2011).

In the blue glaze of the two archaeological artefacts studied in detail (tazza and fragment of a jug) two generations of the tin oxide particles with different morphology and size were detected on the BSE images. It is well-known that the tin oxide opacifier added to the glaze dissolves and recrystallizes during firing (and subsequent cooling) (Moler a et al. 1999; TiTE et al. 2008). Therefore, the larger angular tin oxide particles are remnants of the raw material, while tiny needles are in situ newly-formed tin oxide crystallites (BAJNóczi et al. 2014).

The cobalt colorant associated with nickel and arsenic in the blue glaze of the Hutterite and Haban ceramics indicates the use of a blue pigment made of impure cobalt oxide prepared by roasting arsenic-bearing cobalt-nickel ore minerals (like arsenides, arsenosulphides or arsenates) (BAJNóczi et al. 2014). Zinc detected in the blue glaze of the bowl and the jug also originates from the cobalt-bearing pigment (Ridovics et al. 2015). The blue pigment can be zaffre (roasted cobalt ore, impure cobalt oxide) or smalt (glass obtained by melting the roasted cobalt ore together with quartz (sand) and potash) (MüHLETHALER - 
Thissen 1969). Concentration of the cobalt together with the concentration of tin is closely related to the intensity of the blue colour as it was seen for the case of the archaeological artefact from the Buda Castle with the lighter inner glaze containing a smaller amount of cobalt, but a higher amount of tin compared to the outer glaze.

No cobalt- and/or nickel-bearing inclusions related to the pigment were found in the blue glaze of the studied Hutterite and Haban ceramics, only one nickel arsenide inclusion was detected in the blue glaze of the bowl. This phenomenon is in contrast to the blue glaze of the cobalt-blue ceramics from Szászkézd, which contains numerous nickelcobalt-arsenic(-iron)-bearing undissolved pigment particles (BAJNócZI et al. 2011). However, many calcium-lead or lead-calcium arsenate particles were detected in the blue glaze of the studied ceramics. A well-known process occurs during firing (and subsequent cooling) of the blue glaze: the arsenic content of the pigment separates from the cobalt and recrystallizes, mainly in association with calcium and lead, as newly-formed arsenate particles (Zucchiatti et al. 2006). Most of the arsenate particles observed in the studied glaze, namely the tabular and needle-like crystals preferentially deposited inside pores and at the rim of the pores and the arsenate accumulations at the body-glaze interface in the form of stripes are in situ newly-formed inclusions. Similar newly-formed arsenate crystals were detected in the blue decorations of Italian maiolica (e.g. Viti et al. 2003; Dell'Aquila et al. 2006) including $16^{\text {th }}$-century berettino ceramics from Faenza (Tiтe 2009). Although cobalt or nickel are generally not found in arsenic-bearing particles, some of the angular or rounded arsenate inclusions detected in the blue glaze of the bowl and jug might be pigment residues, suggesting the use of zaffre rather than smalt.

The third type of bright inclusions, namely lead antimonate was detected in the blue glaze of two studied ceramics (jug and the archaeological artefact from the Buda Castle - fragment of a jug). Lead antimonate is the typical pigment of the yellow decoration ( $\mathrm{BA}_{\mathrm{A}}$ JNÓCZI et al. 2014); it was added to the blue glaze probably intentionally to modify its hue.

A precursor of the Hutterite and Haban blue-glazed ceramics is the berettino-glazed (light or deep blue-glazed) Italian maiolica. It was produced from the mid-15 $5^{\text {th }}$ century first in Faenza, then later in other ceramic production centres (e.g. Venice and Liguria Genova, Albisola and Savona). Based on the technological studies of RUfFINI et al. (2005) and Tite (2009) the berettino glazes covering the Faenza ceramics are double-layered with a lower opaque tin glaze and an upper transparent glaze, whereas the berettino glazes produced in Venice and Liguria are single-layered only with an opaque tin glaze. The thickness of the opaque berettino glaze varies between 0.20 and $0.46 \mathrm{~mm}$, and the thickness of the transparent glaze on the Faenza ceramics is $0.10-0.20 \mathrm{~mm}$. The chemical composition is also different among berettino glazes produced in different production centres: the opaque part of the berettino glazes from Faenza are characterised by lower lead content $(<19 \mathrm{wt} \%)$ compared to the Venetian and Ligurian berettino glazes $(\sim 18-28$ wt $\%$ ). The $\mathrm{SnO}_{2}$ content is in the similar range between $\sim 2.5$ and $8 \mathrm{wt} \%$ for all berettino glazes.

Regarding the single-layer character of the blue glaze the studied Hutterite and Haban ceramics, especially the archaeological artefacts with a relatively high amount of tin oxide opacifier, are similar to the Venetian and Ligurian berettino glazes. However, the blue glaze made by the Hutterites and Habans seems to be thinner, at least in the studied cross- 
sections. In addition, according to the 'bulk' energy dispersive X-ray measurements, the blue glaze of the studied archaeological artefacts is characterised by a higher amount of lead $\left(\geq 30 \mathrm{wt} \% \mathrm{PbO}\right.$ ) and tin (up to $12 \mathrm{wt} \% \mathrm{SnO}_{2}$ ) than that of the Venetian and Ligurian berettino glazes.

\section{CONCLUSIONS}

The archaeometric analyses performed using handheld XRF and EMPA techniques confirmed that tin (tin oxide opacifier) was deliberately added to the blue glaze of the studied Hutterite and Haban ceramics, including the vessels produced by the "mining town" workshop. The intentionally added tin in the single-layer glaze indicates that the tin glaze technique and not an engobe covered with transparent glaze was used during production. Based on the presence of tin, regardless of its amount, blue-glazed Hutterite and Haban ceramics can be regarded as faience, that is, tin-glazed earthenware. However, the very small amount of tin $(<0.2 \mathrm{wt} \%$ Sn detected by handheld XRF) occurring as heterogeneously distributed tin oxide particles in the blue glaze of the Haban ceramics belonging to the "mining town" workshop cannot give enough opacity to the glaze to adequately conceal the ceramic body. For these objects the opacity is mainly produced by other discrete particles like $\mathrm{SiO}_{2}$ and arsenate crystallites present abundantly in the glaze.

The handheld XRF analysis is proved to be a useful, rapid and non-destructive technique to detect small amounts of tin in a glaze, and to map the variations of tin concentration among glazed ceramics.

\section{ACKNOWLEDGEMENTS}

We are indebted to restorers Judit Löricz (Hungarian National Museum), Kornélia Hajtó and Katalin Csontos (Museum of Applied Arts) for their help during sampling. The artefact (tazza) excavated at the gun-foundry in the outer castle of Sárospatak was provided by archaeologist István Ringer (Rákóczi Museum of the Hungarian National Museum), whereas the blue-glazed fragment excavated at the Buda Castle by archaeologist Anikó Tóth was provided by Eszter Kovács (Budapest History Museum). This study was supported by the Hungarian Scientific Research Fund (OTKA K81201, K81213 and K81133) and the János Bolyai Research Scholarship of the Hungarian Academy of Sciences (granted to BB).

\section{LITERATURE}

BAJNóczi Bernadett - NAGY Géza - MAY Zoltán - Tóth Mária

2011: Adalékok a szászkézdi kerámiák készítési technikájához anyagvizsgálatok alapján [Findings of an examination performed on the material of Szászkézd ceramic]. Néprajzi Értesitö, 93, 95-109.

BAjNóczi Bernadett - NAgy Géza - Tóth Mária - Ringer István - Ridovics Anna

2014: Archaeometric characterization of 17th-century tin-glazed Anabaptist (Hutterite) faience artefacts from North-East-Hungary. Journal of Archaeological Science, 45, 1-14. 
BALla Gabriella - RadvÁNYi Diána

2007: Néhány sor a habán kerámiák készítés-technikájáról [The technique of making Haban ceramics]. In: RÉTI László (ed.): Habán mítosz 1593-1738. Magyar magángyüjtemények kincsei. Iparművészeti Múzeum, Budapest, p. 24.

BunTa Magda

1973: Az erdélyi habán kerámia [The Haban ceramics in Transylvania]. Bukarest, Kriterion Könyvkiadó, 106 p.

Dell'Aquila, C. - Laviano, R. - Vurro, F.

2006: Chemical and mineralogical investigations of majolicas $\left(16^{\text {th }}-19^{\text {th }}\right.$ centuries $)$ from Laterza, southern Italy. In: Maggetti, M. - Messiga, B. (eds.): Geomaterials in Cultural Heritage. Geological Society, London, Special Publications, 257, 151-162.

Horváth, J. Eugen - H. Krisztinkovich, Mária

2005: A history of Haban ceramics. A private view. A Canadian Collection of Hungarica, Volume IV, Vancouver BC Canada, 398 p.

KATONA Imre

1976: A habán kerámia Magyarországon [Haban ceramics in Hungary]. Budapest, Képzőmüvészeti Alap Kiadóvállalata, 2nd edition, 227.

2001: Habánok Magyarországon [Habans in Hungary]. Budapest, Gesta Könyvkiadó, 198.

Molera, J. - Pradell, T. - Salvadó, N. - Vendrell-Saz, M.

1999: Evidence of tin oxide recrystallization in opacified lead glazes. Journal of the American Ceramic Society, 82, 2871-2875.

Mühlerthaler, Bruno - Thissen, Jean

1969: Smalt. Studies in Conservation, 14, 47-61.

Pradell, T. - Molera, J. - Salvadó, N. - Labrador, A.

2010: Synchrotron radiation micro-XRD in the study of glaze technology. Applied Physics, A99, 407-417.

RADVÁNYI Diána

2011: A habánok kerámiamüvessége [The ceramic craft of the Habans]. In: RADVÁNYi Diána - RÉTI László: A habánok kerámiamüvészete. A Kárpát-medence kerámiamüvészete sorozat IV. kötete [The ceramic art of the Habans. Volume IV of the series The ceramic art of the Carpathian Basin] (series ed.: Vörösváry Ferenc), Budapest, Novella Kiadó, 25-33.

Ridovics Anna - May Zoltán - BAjNóczi Bernadett - Tóth Mária

2015: Examination of Haban vessels with uranium-bearing blue glaze. Acta Ethnographica, 60, 485-514.

Ruffini, A. - Gualtieri, S. - Fabbri, B.

2005: Comparison between Renaissance "berettino" glazes from some ceramic centres in Northern Italy. In: Kars, H. - Burke, E. (eds.): Proceedings of the 33rd International Symposium on Archaeometry, 22-26 April 2002, Amsterdam. Geoarchaeological and Bioarchaeological Studies 3, Institute for Geo- and Bioarchaeology, Vrije Universiteit, Amsterdam, 249-252.

Tite, M. S.

2009: The production technology of Italian maiolica: a reassessment. Journal of Archaeological Science, 36, 2065-2080.

Tite, M. S. - Freestone, I. - Mason, R. - Molera, J. - Vendrell-Saz, M. - Wood, N.

1998: Lead glazes in antiquity - methods of production and reasons for use. Archaeometry, 40, 241-260.

Tite, M. - Pradell, T. - Shortland, A.

2008: Discovery, production and use of tin-based opacifiers in glasses, enamels and glazes from the Late Iron Age onwards: a reassessment. Archaeometry, 50, 67-84.

Viti, C. - Borgia, C. - Brunetti, B. - Sgamellotti, A. - Mellini, M.

2003: Microtexture and microchemistry of glaze and pigments in Italian Reneaissance pottery from Gubbio and Deruta. Journal of Cultural Heritage, 4, 199-210.

WARTHA Vince

1892: Az agyagipar technológiája [Technology of clay industry]. Budapest, Természettudományi Könyvkiadó-vállalat.

Zucchiatti, A. - Bouquillon, A. - Katona, I. - D’Alessandro, A.

2006: The Della Robbia blue: a case study for the use of cobalt pigments in ceramics during the Italian Renaissance. Archaeometry, 48, 131-152. 